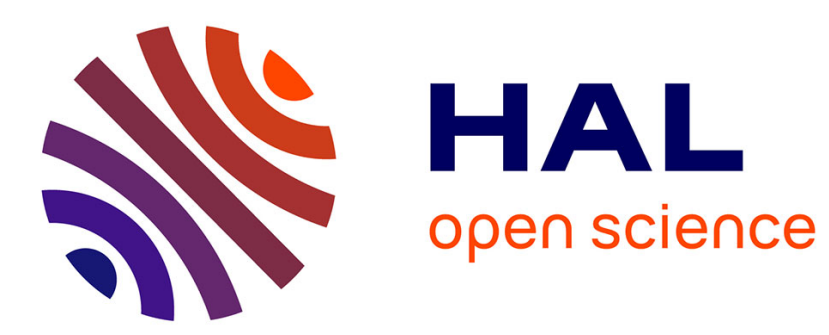

\title{
De-Stalinisation in Hungary from a Gendered Perspective: The Case of Júlia Rajk.
}

\author{
Andrea Petö
}

\section{To cite this version:}

Andrea Petö. De-Stalinisation in Hungary from a Gendered Perspective: The Case of Júlia Rajk.. DeStanising Eastern Europe. The Rehabilitation of Stalin's Victims after 1953. Eds. Kevin McDermott, Matthew Stibbe, Palgrave Macmillan, 2015. hal-03215552

\section{HAL Id: hal-03215552 https://hal.science/hal-03215552}

Submitted on 6 May 2021

HAL is a multi-disciplinary open access archive for the deposit and dissemination of scientific research documents, whether they are published or not. The documents may come from teaching and research institutions in France or abroad, or from public or private research centers.
L'archive ouverte pluridisciplinaire HAL, est destinée au dépôt et à la diffusion de documents scientifiques de niveau recherche, publiés ou non, émanant des établissements d'enseignement et de recherche français ou étrangers, des laboratoires publics ou privés. 


\title{
PROOF
}

\section{3 \\ De-Stalinisation in Hungary from a Gendered Perspective: The Case of Júlia Rajk}

10

11

12

13

\author{
Andrea Petó
}

'Grief is the common language of humanity,' commented Radio Free Europe on 6 October 1956 at the time of the reburial of László Rajk, the hardline communist Minister of the Interior in Hungary, who was executed as an alleged 'Titoist' after a show trial in 1949. ${ }^{1}$ In this chapter, I analyse two unique features of the process of de-Stalinisation in Hungary. The first is its timing: the process began much earlier than in any other eastern bloc country, and indeed almost immediately after the death of Stalin, with the appointment of a reformist, Imre Nagy (1896-1956), as Prime Minister in July $1953 .^{2}$ The second is the key role played in the process by a woman, namely Júlia Rajk (1914-1981), László Rajk's widow. The two processes are linked, as Júlia Rajk and her husband belonged to a privileged group in post-1945 Hungarian society, having been prominent members of Hungary's underground communist movement in the 1930s and early 1940s. Yet this influential couple, and their infant son, fell victim to the first Soviet-style show trial in Hungary in 1949.

Júlia Rajk, born as Júlia Földes in 1914, grew up in Budapest in a working-class family that had strong communist traditions. ${ }^{3}$ In the 1930s she lived for a while in Paris and became active in promoting Red Aid for Spain. She re-entered Hungary at the beginning of the Second World War and worked illegally for the party, before being arrested, with her husband, by police loyal to the fascist Arrow Cross regime in December 1944. Between 1945 and 1949, as the wife of László Rajk, who had also been a legendary leader in the Spanish Civil War, Júlia Rajk (known in Hungary as Rajk Lászlóné or Mrs László Rajk) became a leading functionary in the communist-controlled Democratic Association of Hungarian Women (MNDSZ). In a trial that took place in March 1950, nine months after her arrest, she received a five-year prison sentence, 
having been convicted of supporting her husband's so-called 'subversive policy'. On completion of her sentence, she was released from prison in June 1954 as Györk Lászlóné (Mrs László Györk). She signed her subsequent appeals to the leaders of the Hungarian communist party requesting official rehabilitation using both names - Rajk Lászlóné and Györk Lászlóné. The son of Júlia and László, also called László, was a five-month-old baby when his mother was arrested in June 1949. The infant was taken to an orphanage and renamed István Kovács, the most common name in Hungary. After László Rajk's reburial on 6 October 1956, Júlia regained the right to use her married name (Mrs László Rajk) and her son once again became László Rajk Jr.

Two names and two personalities in post-1945 Hungarian history became taboo subjects. The first was Júlia's executed husband, László Rajk (1909-1949), who was posthumously rehabilitated and reburied in 1955-1956. The second was Imre Nagy, who, having lost office in April 1955, served again as Hungarian Prime Minister during the Revolution of October-November 1956. Nagy was executed as a traitor in 1958 and buried in an unmarked grave; his reburial in 1989 marked the end of communism in Hungary. The link in the public mind between the two names is based in part on the high-profile political role played by Júlia Rajk. Like Nagy, she took refuge in the Yugoslav embassy on 4 November 1956, and was part of the group removed to Romania after the completion of the Soviet invasion, although, luckily for her, she did not face any criminal charges in relation to the events of 1956. She was granted permission to return to Hungary in October 1958, and gradually became a key figure in the opposition movement, demanding the rehabilitation of Nagy and his fellow martyrs.

The most striking aspect of Júlia Rajk's life, however, was her relentless insistence on achieving her husband's unconditional political rehabilitation. This moral human achievement is all the more remarkable given that it was founded on Júlia's capacity for self-effacement and her refusal to dwell on her own plight. As she lacked any formal power within the party, her mastery of the universal 'language of grief' played a crucial role in spurring decision-makers in the nomenclature into action. The 'language of grief' is first and foremost a women's language, and this gave Rajk her confidence. Standing up for her executed husband gave meaning to her own years in prison. As a wife fighting for the honourable burial of her husband, she was also raised above the controversies and dividing lines of Hungarian politics more generally. The struggle, however, did not end with the graveside photograph of Júlia accompanied by her son, taken at her husband's reburial at the 
Kerepesi cemetery in Budapest and published in the international press. The fact that a reburial was held inspired the leaders of the Hungarian Revolution, who saw how it was possible, using the telephone, to mobilise hundreds of thousands of people for a 'cause'. The implacability of Júlia Rajk and her insistence on the broadest publicity for her husband's reburial on 6 October 1956 rendered the event a psychological dress rehearsal for the 1956 Revolution.

In later periods too, Júlia Rajk campaigned consistently for the full rehabilitation of the victims of Stalinist terror. However, the victims for whom she fought had all belonged to one or another branch of the Hungarian labour movement, whether as communists, social democrats or unaligned 'progressives', and all of them had been subjected to the unlawful actions of the regime in the period of 'high Stalinism' between 1949 and 1953. The victims of political terror in the years 1945-1948, which had seen the complete replacement of Hungary's political elite, the nationalisation of its industry and commerce, the persecution of leading figures in the Church, the repression of anti-regime elements linked to the army or the middle-class Smallholders' Party, and trials of alleged economic 'saboteurs', lay outside her area of interest. ${ }^{4}$

In this chapter, I shall first briefly explore the life of Júlia Rajk, and then turn to the history of the rehabilitation process in Hungary up until the crucially important reburial of László Rajk. I shall show how Júlia Rajk utilised the 'language of grief' in her relentless struggle against two key political figures in post-war Hungarian history: Mátyás Rákosi (1892-1971), who was General Secretary of the Hungarian communist party from February 1945 to July 1956; and János Kádár (1912-1989), Minister of the Interior from 1948 to 1950 and himself a victim of the purges, who spent the years 1951 to 1954 in jail, only to be released, rehabilitated and elevated to the posts of party General Secretary (on 24 October 1956) and Prime Minister in place of Nagy (after the Soviet invasion on 4 November 1956). Both men personally sabotaged any real attempts to work through the past, including their own shadowy roles in the Rajk trial and related abuses of state power. They could do so only as long as they could argue that confronting the crimes of the past would merely assist the enemies of communism.

\section{The struggle for her own rehabilitation}

Júlia Rajk could not believe she was being set free when, on 14 June 1954, at the end of her five-year sentence, she was taken from her cell to the prison gates. After her release, with an identity card issued in the 


\section{PROOF}

name of Mrs László Györk, she began a new life. She had nothing, as all her property had been confiscated. On 8 July 1954, the Ministry of the Interior ordered its Department of Investigations to conduct a review into the case of Mrs László Rajk. ${ }^{5}$ To proceed with an appeal hearing, the documentation from the 1950 trial was required. However, 'despite a diligent search of the operational records at the Ministry of the Interior, the official record could not be found', so the investigators had 'no option but to reconstruct it' ${ }^{6}$ In other words, all the official papers and documents that the court needed to see before it could consent to an appeal were missing. Witnesses later complained that at the new trial in 1955 , they were put under pressure to say things, just as they had been in $1949 .^{7}$

The case review was concluded on 9 September 1954 with the finding that the original conviction was unsafe. In his summing up on 14 September 1954, Kálmán Czakó, the Chief Public Prosecutor, drew the following conclusion: 'We have further established that Mrs László Rajk could not have taken part in the conspiracy organised by her husband, as there was no such conspiracy, and none of the people questioned had any knowledge of it, whereby Mrs László Rajk could not have known about it either. ${ }^{\prime 8}$ In a report dated 24 September 1954, Czakó recommended an appeal hearing for the former MNDSZ functionary Mrs László Rajk, merging the case with two others, namely the case of Márta Tauszky, who remained in detention and would later be convicted of espionage, and the case of the industrial turner Imre Gayer, who had already been executed. The manner of the review procedure was just as impersonal and humiliating as the original court hearing. Neither the original hearing nor the review into it made reference to the nature of the case. The official application for an appeal hearing stated dryly that Mrs László Rajk had served her sentence and that her 'acquittal was to be expected'. It also indicated that witnesses named Boris Fái, Mrs Döbrentei and Faludi, former colleagues of Júlia Rajk, would be AQ2 called to give evidence. ${ }^{9}$ A copy of each of these reports was submitted to Rákosi's secretariat, which was closely monitoring developments. ${ }^{10}$

The appeal hearing began on 12 October 1954 and ended on 26 July 1955, when a closed session of the Special Council of the Supreme Court, citing lack of evidence, acquitted Mrs László Rajk of taking part in a conspiracy to overthrow the people's democratic state order. In its grounds for the verdict, the court noted that in the original case, both the police and the court had proceeded in an unlawful fashion. It also acknowledged that with respect to her work for the MNDSZ, 'no more than a distant link can be made with the acts mentioned in the 


\section{PROOF}

indictment'. ${ }^{11}$ However, the veracity of the two witness statements that were said to be 'indifferent' was upheld. Indeed, the witnesses repeated word for word the statements that they had made in 1949, according to which Mrs László Rajk's work in the MNDSZ had been less than adequate; in fact, her performance was branded a failure. ${ }^{12}$ In another humiliation, she was asked by the prosecutor whether it was true that on hearing of Rajk's death she had welcomed the news, as it meant she would get his watch. Júlia, with her experience of prison life, knew that watches were the objects that disappeared first. ${ }^{13}$ Thus, although she received a legal rehabilitation, it did not amount to a moral or political one. People were dissatisfied with the appeal hearing, and regarded it as being no less defective then the original show trial.

Beyond the appeal hearing, rehabilitation was a slow and gradual process. Mrs László Rajk continuously bombarded party comrades with letters, requesting a resolution of 'the matter'. The 'matter' in question was the restoration of her party membership, which turned out to be a good choice of approach for several reasons. Party membership was a 'sacred' issue: it was subject to the judgement of fellow communists, the only valid reference group in the eyes of loyal party members. Júlia also knew how she could influence this decision-making group by way of her political contacts. As a reinstated party member, she could make better use of her policy of 'being personally present', for in her person and by way of her person she was living evidence that crimes had been committed by the Rákosi regime between 1949 and 1953. It is no surprise to learn that letters from Mrs Rajk and encounters with her so alarmed communist functionaries that they duly filed reports to their superiors.

This is what happened on 17 August 1955, when, at a personal meeting, communist official Lajos Ács handed Mrs László Rajk her renewed party membership card, while nonetheless informing her that she had received a severe reprimand. Such disciplinary measures were no joke - the party statutes determined exactly who could be reprimanded and at what forum. In such cases, the 'culprit' was entitled to attend the disciplinary meeting. In Júlia's case, however, a formal error had occurred. As Ács informed her, she had been reprimanded for failing to tell the party that in late 1944, while she and her husband were being held prisoner by the Arrow Cross, László Rajk had denied his communist past. This accusation repeated the false logic of the 1949 show trial, because it was clear to everyone that Júlia could not have been present in person when her husband allegedly made the statement in question. Mrs Rajk could not be intimidated. In a letter to the Central Party 
Control Commission (CPCC), dated 18 August 1955, she demanded a full public hearing so that she could prove - with witnesses - that she had been telling the truth. For the CPCC, another public hearing was the least attractive option. However, for Júlia, who had considerable experience of 'Kremlinology', the tone and content of Ács's message indicated that her struggle was far from over, as 'given the manner of the 'rehabilitation' of my husband, Comrade László Rajk [she considered it important to emphasise the comrade part, but the italics are mine, A. P.], it is now clear to the entire international working class that, in place of the trumped-up charges, further accusations - ones that have already been made in the past [concerning events in 1944] - are to be brought against him'.

At the fateful meeting with Ács on 17 August 1955, Júlia fought tooth and nail for her cause: she expressed her 'indescribable joy, relief and pride at becoming a party member once again'. Party membership also meant protection: 'Now that I have been returned my party membership card, I consider it my communist obligation to fight for the party in an even more consistent and determined manner than before. ${ }^{14}$ Probably, it was this that most worried the party leaders, who were rather fearful of meetings with her, and sought, where possible, to delegate the task of talking with her to subordinates. For her part, Júlia did not expect to receive any favours or good-will from the party, even if it did quietly rescind the decision to reprimand her. In her ongoing battle for justice, she looked for and found allies among those repressed leftists and party veterans who supported the process of working through the past.

\section{The rehabilitation of László Rajk}

At her appeal hearing in July 1955, Júlia made use of her right to the last word to highlight three goals: 'I ask that my husband László Rajk be rehabilitated, that I should be allowed to bury my husband, and that my son be given back his real name. ${ }^{\prime 15}$ Yet her most important demand was the following: 'My wish and my request is that my name be restored to me. ${ }^{\prime 16}$ The fight to win back her name was part of the struggle to rehabilitate László Rajk; its outcome would determine not only Júlia's own fate and that of her son, but also the fate of the whole country.

Securing full moral and political rehabilitation was no easy task, however. The case of László Rajk had fundamentally altered the communist party apparatus's outlook on life. Members of the party apparatus were initially made to believe that Rajk had been a traitor. Now they were being told that this had not been the case. Perhaps the best 


\section{PROOF}

way to illustrate the party apparatus's distorted perception of Rajk in the mid-1950s is to cite the generally held opinion that he was guilty of deliberate deception because he had falsely confessed to the charges against him during his trial in September 1949 and had thus misled thousands of loyal party workers. Rajk's apparent submissiveness would subsequently be addressed by Júlia in an essay published in 1969. ${ }^{17}$ Until that time, however, she had to sit through the appeal hearings, which continued to search relentlessly for suspicious events in the life of her executed husband.

The Department of Investigations of the Ministry of the Interior began its review of the Rajk case on 3 May 1954. It reported on its actions on an ongoing basis to the Department of Special Affairs of the Chief Public Prosecutor, Czakó. An official inquiry was ordered by the Minister of the Interior, László Piros, on 9 July 1954. The reports examined the veracity of various witness statements made in the case, but the drafters of the reports received no guidance as to a 'new concept or strategy', and thus they awaited instructions. Most of the cadres working on the review were trusted members of the old guard. A report dated 3 September 1954 examined whether or not László Rajk had worked as a police informer under the pre-war, anti-communist Horthy regime, following his first arrest in $1931 .^{18}$ An investigation of this issue bore little political risk, because in the 1930s, most of the leaders of the Hungarian communist party, including those still in the top positions in the 1950s, were already in exile in Moscow, and thus could not be implicated. A summary report was drawn up, with five incriminating arguments and 12 exonerating arguments. The investigation related to Rajk's activities up to the end of the Second World War, with the aim of discovering signs of treachery. Included in the evidence cited was a witness statement by Mrs László Rajk recalling that László Rajk had made no mention of being a police informer during his trial by the Arrow Cross in March 1945. ${ }^{19}$ The summary report, noting that the confessions during the 1949 interrogations and trial had been made under duress, recommended a new trial and the release from prison of the surviving members of the Rajk group.

The political context was now broadly favourable, as the rehabilitation of communists sentenced in show trials was crucial to the 'New Course' implemented by Nagy during his first term as Prime Minister from July 1953 to April 1955. ${ }^{20}$ On 18 September 1954, Czakó submitted to the Chairman of the Supreme Court a motion for the retrial of László Rajk and two others who had been executed as alleged co-conspirators, Tibor Szőnyi and András Szalai. ${ }^{21}$ In a further memorandum sent to 
Nagy on 22 September 1954, Czakó proposed an appeal hearing for Rajk and his associates. The memorandum was also received by the party General Secretary, Rákosi. ${ }^{22}$

For the party, of course, it was clear that 'Case No. 1' was the most sensitive of all the cases now under review relating to communists sentenced in show trials. There were three big risk factors: first, a fear of addressing the issue of responsibility and in particular of naming those ÁVH (secret police) officials who had been involved in extracting false AQ3 confessions; second, the issue of how to handle the shadowy role of Soviet advisers; and third, the likely continued presence of Júlia Rajk at the appeal hearings. Indeed, the latter did not hesitate to tell informal contacts, acquaintances and colleagues about the rehabilitation process and the anomalies surrounding it. Moreover, she openly discussed developments with her friends - and this at a time when Khrushchev's 'secret speech' condemning Stalin was still well over a year away. All of these risks, and especially the last, threatened the authority of the party and ultimately came to undermine the entire Rákosi regime. This in turn highlights three unique features of the de-Stalinisation process in Hungary - the decision to start reviewing show trials involving communists and social democrats at an early stage after Stalin's death; the difficulties caused by the party's inability to keep the existence of such appeal hearings secret; and its failure to prevent released prisoners or relatives of executed party comrades from speaking out.

By November 1954, according to a report written by the Deputy Minister of the Interior and ÁVH Major-General István Dékán, 89 case reviews had been completed, including those of Júlia Rajk and the future party General Secretary Kádár, the latter having been released in July 1954 from a life sentence imposed after a show trial in December 1952. ${ }^{23}$ A follow-up report, dated 28 December 1954, stated that 'we have established that the political crimes of László Rajk and his associates did not exist in reality'. ${ }^{24}$ However, in the winter of 1954-1955, further progress was delayed by a power struggle in the highest echelons of the party leadership. ${ }^{25}$ On 17 February 1955, Prime Minister Nagy sent a letter to the Politburo in which he expressed his profound dissatisfaction at the slowness of the case review process. Two factors were causing delays: first, the weakness of the three-member rehabilitation commission, appointed by the Politburo in May 1954 to establish a framework for dealing with cases where party comrades had been wrongly convicted. According to Nagy, this commission was incapable of accomplishing its task', treated the written evidence as its own property, and refused to share it with members of the Politburo. The other reason was 
difficulties in 'holding to account those against whom grave evidence had arisen in the course of the investigations', namely police interrogators. Nagy proposed the disbandment of the commission and recommended that future decisions should be taken directly by the Politburo. He threatened to resign if his proposals were rejected, because he 'could not accept responsibility' for what was happening. ${ }^{26}$ The letter suggests a certain amount of naivety on Nagy's part; he seems to have failed to recognise the three-member commission's true purpose (to preserve the authority of the party) and vainly hoped that the Politburo's involvement would guarantee the continuation of the rehabilitation process.

Such hopes were reinforced when, in a letter to the Central Committee on 9 February 1955, Minister of the Interior Piros listed the names of the ÁVH officers who had committed criminal acts. He proposed that the officers in question be investigated by a committee of state security officers and then be sentenced to expulsion from the party and/or imprisonment. ${ }^{27}$ However, in April 1955, Nagy himself was dismissed as Prime Minister and deprived of his membership of the Politburo and Central Committee, rendering him no longer able to influence events from the inside. The three-member rehabilitation commission now comprised Rákosi, Lajos Ács and Antal Apró. The latter had been coopted as a recent beneficiary of the rehabilitation process and was very willing to cooperate. ${ }^{28}$

In a report on 6 April 1955, the Department of Investigations of the Ministry of the Interior warned of the greatest danger presented by the appeal hearings: 'When the convicted state security officers are being heard [as witnesses], in particular Gábor Péter [the former head of the ÁVH who was himself purged and imprisoned in 1952], attention must also be given to the fact that they will try to shift responsibility for the cases they fabricated onto some of the Party leaders and onto Soviet comrades, and it is inevitable that the names of some of the members of the party's Central Committee will feature in the proceedings. ${ }^{29}$ Mentioning such names was, of course, taboo. In June 1955, the Ministry of the Interior came up with a solution when it suggested that the 'top secret nature' of the Rajk case made it vital to ensure that the appeal hearing 'be divided into separate parts and [that] only the most necessary persons [are] examined as witnesses' ${ }^{30}$

In July 1955, the Politburo decided to accelerate the rehabilitation process, whereby, with the exception of the Rajk case, 'all other cases should be concluded' by mid-October. ${ }^{31}$ The appeal hearing for László Rajk and his associates was delayed until 23-25 November, when it was finally held at the Hungarian Supreme Court. ${ }^{32}$ Prior to the hearing, 
however, Rákosi gave a report on 'new' developments in the 'Rajk case' at a Politburo meeting. He stated that Rajk had been responsible for Hungary's worsening relations with Yugoslavia, because 'he had kept the party in the dark about his first detention [in 1931] and the grave circumstances surrounding it'. ${ }^{33}$ Shortly before this meeting, on 5 November 1955, the rehabilitation commission had come to a decision concerning the witnesses. As far as cases subject to review were concerned, the commission's report mainly cited the witness statements and accounts used at the original trials, and did not challenge their veracity. At the carefully staged appeal hearing for Rajk and associates, the witnesses were asked the very same questions, and in their responses they repeated their previous statements word for word, in the arcane language of party functionaries. ${ }^{34}$ Moreover, the witnesses made no attempt to present László Rajk in a positive light. Indeed, when he was called to give evidence on 24 November 1955, István Tömpe stated the following: 'In my view, Rajk was a coward in 1949 too, and that is why he agreed to play along with the lie [my italics, A.P.].' ${ }^{35}$

The court acquitted László Rajk of the crime of espionage and conspiracy on grounds of absence of culpability, and it acquitted him of crimes against the people on grounds of lack of evidence. In November 1955, a Central Committee resolution placed the blame on former ÁVH head Péter and on Rajk himself, as the latter had concealed the 'grave circumstances' of his detention in $1931 .{ }^{36}$ In reality, the light sentence received by László Rajk in the case brought against party activists arrested at Budapest University in 1931-1932, which was repeatedly mentioned as suspicious 23 years later, reflected his minor status in the trial and the fact that - not for the first time - the Horthy regime's police force was unaware of his real identity as a leading communist functionary. Furthermore, none of his co-defendants in 1932 had incriminated him. In short, even though László Rajk was found innocent of the criminal charges that he had faced in 1949, some of the witness statements at the appeal hearing, and the Central Committee's November 1955 resolution on the case, placed him under continued political and moral suspicion. The battle to restore his reputation was still not over.

\section{The contradictions and complexities of rehabilitation}

In accordance with the instructions of the party leadership, the rehabilitation of party members was supposed to be carried out in 'greatest secrecy'. Júlia Rajk fought against this tendency, whereby her first step 
was to use the name Mrs László Rajk. For instance, although she was examined at the Supreme Court during the appeal hearing for László Rajk in November 1955 as 'Mrs László Györk', she nevertheless signed her statement as 'Mrs László Rajk'. On hearing the name Rajk, many party members felt a shiver go down their spines - either because they had allowed themselves to be persuaded of László Rajk's guilt or because they had testified against him in various public forums or even in a court of law.

After the appeal hearing for László Rajk and his associates in November 1955, the regime applied pressure on Júlia by way of the party secretary in the Eighth District of Budapest, where the Szabó Ervin Library - her place of employment since February 1955 - was situated. It assigned József Suhajda the task of persuading her of the 'incorrectness of her position' and that her attitude 'was causing many problems, as she merely criticised and refused to accept help'. Suhajda agreed to undertake the task - doing so, however, against his better judgement ('It would have been better to reject the task'). He told Júlia that 'although her conduct was fully understandable given what had happened to her murdered innocent husband, it was nevertheless very costly and was preventing closure'. In response, Júlia employed a tactic that had already proved successful: she openly stated her opinion and then told Suhajda what she had experienced. The loyal party functionary Suhajda was so shocked by Mrs Rajk's words that he could still remember them almost 30 years after their meeting: 'Do you not know that, despite all the promises [that his life would be spared if he confessed], my husband was taken to the gallows and that he was still saying "Long live the party! Long live the Soviet Union"?' Suhadja questioned how Rajk had allowed himself to get into such an awkward position. 'Why did they not get people to talk to her who had worked with her husband and who knew what had happened? I couldn't give answers to a lady devoured by pain [my italics, A.P.].' Júlia's words evidently came as a shock to this party functionary; he was confronted by a wife in mourning for her husband, who was merely asking for justice, and for her husband to receive the proper funeral he deserved. ${ }^{37}$

The November 1955 resolution of the Central Committee on the Rajk case, blaming Péter and Rajk himself, was made known to Júlia, in accordance with the Central Committee's wishes, by way of the party branch organisation at the Szabó Ervin Library. Júlia apparently stood up and stated that she disagreed with the contents of the resolution. She asked for the matter to be investigated by the CPCC and the Central Committee. ${ }^{38}$ Her words appear to have had an effect. In a letter dated 


\section{PROOF}

7 December 1955, 'Comrade Mrs László Rajk' was asked to attend an appointment in Akadémia Street at 10 a.m. on 8 December. ${ }^{39}$

Not much remains by way of records of this meeting or of Júlia's subsequent correspondence with the party leadership. Her main achievement was to compel the party bosses to address her concerns; they could not simply pretend that she did not exist or that her name was Mrs László Györk. Whenever she felt she was being mistreated, she would immediately pick up a pen and write. Her most important demand was that her husband should receive a proper burial. ${ }^{40}$

In April 1956, Apró, in his capacity as a member of the rehabilitation commission, prepared a report for the Politburo on the principles governing the rehabilitation of those senior party comrades who had been wrongly convicted and who were entitled to have their expulsion from the party reviewed in line with a Politburo resolution of 21 May 1954. According to the report, cases concerning 234 individuals had been investigated. Of this number, 132 individuals had been convicted and imprisoned, 102 had been acquitted, 43 had spent time in pretrial detention, 18 had been interned, and 41 were relatives of those sentenced..$^{41}$ By now the wildest rumours were circulating about Júlia Rajk - for instance, that she was to receive a villa in the Second District of Budapest, or a monthly pension of 5,000 forints, or a job as manager of the most beautiful patisserie in Budapest. It was even alleged that Tito had personally sent her money via the Yugoslav embassy in Budapest. ${ }^{42}$ However, the report simply stated that her party membership had been restored and that she had received compensation amounting to 92,193 forints, a two-roomed apartment with middle-class comforts [my italics, A.P.], child benefit of 700 forints, an annual four-week holiday, and an $\mathrm{AQ4}$ entitlement to special hospital treatment and to convalescence at a sanatorium. She had received more than any other rehabilitated individual, but not as much as the rumours claimed. The report also detailed the rehabilitation of other members of the Rajk family who had received party punishments in the aftermath of the 1949 trial. ${ }^{43}$

The question of financial compensation to rehabilitated communists was initially handled by the Ministry of the Interior, but was later managed by a party commission headed by Apró. This was one area, indeed, where the party felt able to compromise. In total, rehabilitation resulted in the payment of a sum of 4.9 million forints to the victims, and this was coupled with the awarding of 150 apartments, 245 one-week holidays, and 63 hospital treatments. But there were also weaknesses in the process, including, as even Apró admitted, a failure to settle financial matters in a satisfactory manner. The court proceedings were 'slow and 
gradual', and 'were not receiving adequate publicity, which resulted in further delays and the unsatisfactory treatment of rehabilitated persons by certain bodies and functionaries'. Furthermore, 'relatives of the executed individuals questioned why they were not permitted to exhume the bodies of family members'. ${ }^{44}$

At a meeting on 19 April 1956, the Politburo approved a list of rehabilitated party members and then passed a resolution ordering that posthumous rehabilitation notices be read out at the former workplaces of the deceased by 31 May at the latest. It also stipulated that the Chief Public Prosecutor should issue certificates stating cause of death to the relatives. ${ }^{45} \mathrm{~A}$ symbolic moral rehabilitation of those communists who had been executed as supposed traitors thus took place, but controversies surrounding their funerals and reburials still lay ahead.

\section{Reburial}

In her battle for the memory of her husband and for her own name, Júlia Rajk was forced to fight on several fronts. First, on account of her husband's term as Minister of the Interior, she had to deal with the hostility of those who were opposed to the party and its stranglehold over Hungarian political life. Also hostile to her were exiles in the west, who struggled to fathom the 'emotional myths' that arose around a man who had once been the iron-fist Minister of the Interior for a communist regime. Meanwhile, the old party leaders, people who at one time had been close comrades of her and her husband, publicly called Mrs Rajk a traitor to the workers' movement. In spite of these attacks (or perhaps because of them), Júlia Rajk did not give up. She was determined to have her husband properly buried and to win back her name.

The public debates held by the Petőfi Circle, a new forum for dissident opinion, helped to prepare the way intellectually for the revolution of October-November $1956 .{ }^{46}$ The Circle's 'partisan debate', held on 18 June 1956, and attended by many former members of the underground communist movement, was Júlia's first public appearance as Mrs László Rajk since 1949. Her speech on that day was particularly significant because it established the linguistic framework for faithful communists to express their criticism of the past actions of the Rákosi regime. Unlike previous meetings held by the Petôfi Circle, at the 'partisan debate' communists who had been sentenced after show trials publicly proclaimed that despite their imprisonment, they still believed in communism and Leninist ideals. What they also wanted, however, were radical changes 
in the policies and composition of the party leadership. Still, for members of the public attending the meeting, the most interesting aspect was to see 'how the communists bash each other in the debate'. ${ }^{47}$ In the end, the meeting lasted until the early hours of the next morning. Its important message was that the communists were now agreed on the need to face up to the past - something they had previously denounced as a fetish of 'right-wing reactionaries'.

The words spoken by Júlia Rajk at the meeting were noted down; they deserve our special attention, as she rarely made public speeches. It is clear even from the edited, published version that it was not a prepared speech. Her words were spontaneous, and she spoke from the heart. When she appeared on the rostrum, she was applauded for around ten minutes. And at the end of her speech, 'the hall resounded with approval'. ${ }^{48}$ She spoke in a clear and considered way, posing many rhetorical questions. The effectiveness of the speech was due to her credibility as one who had suffered at the hands of the Rákosi regime. She compared and contrasted the prisons of the Horthy regime with those of the communist authorities, concluding that prisoners had received better treatment in the former. Rather than make statements, she asked:

How is it possible that the reactionaries saw what the comrades failed to see? Where is the error in the system? What allowed [party officials] not only to make mistakes, but also to commit grave crimes? Where is this error, which still exists? I must say that the people who now want to rehabilitate [the victims] are the same ones who sentenced them, who murdered them, and who sent them to the gallows.

Júlia then analysed the anomalies of the rehabilitation process, in particular the Central Committee resolution of November 1955 concerning the Rajk case. With great conviction, she noted that László Rajk had been a good communist and a suitable role model for young communists.

I feel that the Rajk issue constitutes a part of the process by which they [the supporters of Rákosi] have destroyed this country economically, politically and morally.... Relying on the Hungarian people, we - all of us, the old underground communists and the new intellectuals - must now reinstate Leninist norms. They forced the old comrades out, and this all started with the trial of Rajk in $1949 .{ }^{49}$ 


\section{PROOF}

The message was clear: the old comrades had been purged by newcomers who had caused much damage to the party. The task was therefore to accomplish László Rajk's rehabilitation, because this would allow for a return to the old communist path which had broad national support. Moreover, the spirit of the 20th Congress of the Communist Party of the Soviet Union needed to be applied in Hungary, and this would necessarily result in leadership changes. The speech aroused people's emotions, but it also presented a clear political programme. The personal suffering of Júlia Rajk, the credibility of the 'language of grief', added weight to her words. She received a standing ovation from the 2,000 people in attendance.

Meanwhile, as she still did not know where her husband had been executed or what had happened to his remains, Júlia continued to bombard the authorities with letters. By the spring of 1956 the party leadership was under great pressure. In the wake of Khrushchev's denunciation of Stalin in February, party veterans began making public demands for clear answers concerning the Rajk trial. At a meeting on 24 May 1956, the Politburo reached a decision on additional measures related to the process of rehabilitation. They approved a proposal calling for the creation of a three-member commission, consisting of a member of the Politburo, the Chairman of the Supreme Court, and the Chief Public Prosecutor. It was accepted that there could be no further delays; an authorisation for exhumation of those executed after the Rajk trial would have to be given. ${ }^{50}$

The minutes of the Politburo's meetings show that the party leadership wanted complete control of the reburial event: it was to be attended only by invited comrades, and the party leaders considered it natural that Mrs Rajk would want to take part. On 27 September 1956, the authorities informed the four widows concerned (Mrs Rajk, Szonnyi, Szalai and Pálffy) by telephone that their deceased husbands' bodies had been found and that a burial would take place at the Kerepesi cemetery on the morning of 1 October. They were told to present themselves in Gödöllő in order to identify the bodies. ${ }^{51}$

According to the medical expert, the identification of László Rajk was relatively simple, as the skeletal remains placed on the sheet revealed a man of tall stature with gunshot damage to the forearm, a wound Rajk had received in the Spanish Civil War. Júlia Rajk was visibly shocked by the sight of the 'moldy and ant-ridden collection of bones'. She became even more determined to fight for her husband's full rehabilitation. She also had exact ideas concerning the burial proceedings: 'Since they have already staged a show trial, they should now hold a show burial,' she said. ${ }^{52}$ 
Júlia Rajk never faltered throughout the lengthy process of preparing for the funeral and the controversy over the various arrangements: when and where it should be held, whether to have a funeral bier, who should speak, whether the public should be allowed to attend. She told the authorities that if the public were denied access, she too would lay her flowers at the fence; and she asked for a postponement of the event until 6 October. Until the very last moment, the party leadership refused to countenance a public burial. At Júlia Rajk's behest, the partyopposition made multiple telephone calls in Budapest, telling people that the widows intended to stay away from the funeral unless the authorities relented on their conditions. In this way, within a day or so, the whole of Budapest could be mobilised and pressure placed on the party leadership. It was then that people understood the extent of the power that lay in their hands.

On 5 October 1956, 12 hours before the burial was due to begin, the party leadership finally recognised the embarrassment it would suffer if Mrs Rajk stuck to her word and refused to attend. At the last moment, therefore, they gave permission for the cemetery to be opened to the public. At the burial, both sides wished to avoid a disturbance. 'It is enough if they see just how many we are,' said Júlia's friends, who AQ6 had fresh memories of Soviet tanks on the streets. Everyone was fully aware that the burial represented more than a tribute to the victims; by attending the funeral, people were clearly making a political statement. In the preceding 30 years, no one could remember so many flowers with the same words: 'We shall not forget.' Instead of a small crowd of 'mobilised' party members (which the Politburo had originally anticipated), in the end hundreds of thousands of people passed by the funeral bier and stood at the grave. And all of this was due, first and foremost, to Júlia Rajk's steadfastness.

The burial process itself was of course a historically familiar means of connecting private feelings of mourning with a public performance, while the universal 'language of grief' deployed by Júlia helped to overcome the opposition of the communist decision-makers. Following the iconography of the Pietà, women were mourning men (fathers, sons and partners). In the 1950s secular context, the widows and the orphans of purged party functionaries were also seen first of all as victims, even if the relatives they mourned had at one time been hardline ministers and officials of the communist regime. This opened the way for hundreds of thousands of people to demonstrate their solidarity with four grieving women, who had unjustly suffered the loss of loved ones, while expressing criticism of the communist system in a seemingly non-political way. 
Meanwhile, the 1956 revolution, which began with student-led demonstrations in Budapest on 23 October, opened a new chapter in the process of de-Stalinisation in Hungary. The failure of the Hungarian authorities' cautious approach to rehabilitation in 1953-1955, which had been limited to the elite and barely impacted on ordinary citizens, led inexorably to the 1956 revolution, whereby the reburial of László Rajk and his associates served as a timely rehearsal. On 4 November 1956, when the Soviet army occupied Hungary, Júlia Rajk asked for political refugee status at the Yugoslav embassy. Like Nagy and members of his cabinet, she was subsequently kidnapped by Soviet forces and taken to Romania. She spent two years there, but was then given permission to return to Hungary as Júlia Rajk. After 1958, she was known simply as 'Júlia', becoming a real 'institution' in Hungarian society. Over the years, she became known as someone who always protected the weak against the abuses of the powerful. She also negotiated with the party leadership on behalf of anti-communist intellectuals. She helped establish a dog shelter, the first NGO in Hungary since the imposition of a ban on independent associations in 1951. In a case of transnational activism, she collected signatures in support of the human rights group Charter 77 in Czechoslovakia. At a time when few people made charity donations, Júlia used the compensation she received for the loss of her husband to support a fund for talented university students. When the first proto-feminist movement was organised to protest against a proposed tightening of abortion laws in 1975, she was the first person to sign the petition. Her name at the top of the list served to reassure other participants in the first dissident action in Hungary since 1956. Júlia died in 1981.

\section{Conclusion}

This chapter has examined the first wave of the rehabilitation process in Hungary, which coincided with Stalin's death and Nagy's 'New Course'. In 1956, in the aftermath of the 20th Congress of the Communist Party of the Soviet Union, an investigation was launched into the conduct of members of the state security forces, but its scope was very limited. At a meeting in July 1956, the Central Committee decided to conclude the process of rehabilitation, which had been underway for almost three years and had seriously damaged the party's prestige and authority. It was at this juncture that heads rolled: the party General Secretary, Mátyás Rákosi, was dismissed on 18 July, while Mihály Farkas, the former Minister of Defence, was expelled from the party. In this way, 


\section{PROOF}

the party hoped to achieve closure. Nonetheless, real and unqualified closure was never on the cards, either before or after the 1956 revolution. As Júlia Rajk remarked in an interview in 1980:

One cannot say of murder that it is [due to] the cult of personality. And this was murder. It was an intentional murder ... if a nation fails to confront its past, then its future will also be full of lies. And it is full of lies. In a word, the entire social structure needs to be democratised.... My husband was not rehabilitated. They simply named a street after him. That's not rehabilitation. ${ }^{53}$

On 27 November 1956, after the crushing of the revolution and the assumption of power by Kádár, the Chief Public Prosecutor decreed the collective dismissal of former members of the ÁVH and ordered a review of their previous conduct. The true aim of this measure was to legitimise the establishment of a new state security force rather than to call to account, morally and politically, personnel from the former organisation. We know from research undertaken by Magdolna Baráth that under the terms of the Chief Public Prosecutor's decree, the conduct of 4,986 former ÁVH personnel was reviewed, of whom 3,048 had been active in the operative forces and 1,923 had been working in other areas (office work, dispatch and so on). In total, 4,971 persons whose conduct had been subject to review were exonerated. They received official certificates declaring that they had not been involved in unlawful acts committed by the state security forces. This meant they were employable by any state or communal organ or by a commercial enterprise. Only 15 former members of the state security forces (11 in Budapest and four in other areas of the country) were denied such certificates. ${ }^{54}$ Of $\mathrm{AQ7}$ course, it was unrealistic to expect much from this process, since Kádár, as Minister of the Interior between 1948 and 1950, had himself played an active part in Rajk's demise, just as he had abandoned Nagy in 1956 and allowed him to be executed in 1958.

All of this rendered Júlia Rajk a crucial figure. Utilising the 'language of grief', she fought on the front line for justice - for the communists and social democrats who had been imprisoned or executed under the Rákosi regime, and for their wives and widows who would otherwise have had no one to speak for them in the male-dominated world of Hungarian politics pre- and post-1956. A further round of rehabilitation - undertaken once again rather half-heartedly and limited in scope - began after a Central Committee resolution in 1962. By 17 October 1962, the authorities had received 352 petitions, relating in 
the most part to rehabilitation of purged party members after internment or resettlement (expulsion). In connection with the unlawful trial and conviction of members of the workers' movement, 122 individuals requested financial compensation or other forms of material assistance. ${ }^{55}$ In reality, however, there were hundreds of thousands of victims of Hungary's Stalinist communist regime, and until the late 1980s their chances of rehabilitation were rendered slimmer against an official view of history that still legitimised the communists' coming to power in the late 1940s and depicted 1956 as an attempted 'counter-revolution'.

From Rákosi to Kádár and beyond, selectivity, secrecy and nontransparency of the various waves of rehabilitation since 1953 contributed to a 'war on memory', which only somebody of Júlia Rajk's determination and courage could oppose. In spite of some remarkable moments of reconciliation in Hungarian history since her death, such as the public reburial of Nagy in June 1989, three months before the country's final transition to multi-party democracy, the 'war on memory' continues to this day to characterise the country's politics and even its parliamentary debates, as far as the working through of the communist past is concerned.

\section{Notes}

1. Gallicus in Radio Free Liberty, 22 June 1956, Reflector, No.C-339. Országos Széchenyi Könyvtár (National Szechenyi Library) Radio Free Europe Collection 451/1083. p. 2.

2. M. Baráth, 'Az MDP vezetése és a rehabilitáció (1953-1956)', Múltunk, no. 4. (1999), pp. 40-97.

3. For more on Júlia Rajk, see A. Petó, Rajk Júlia (Budapest, 2001).

4. For a broader overview, see L. Borhi, 'Stalinist Terror in Hungary, 1945-1956', in K. McDermott and M. Stibbe (eds), Stalinist Terror in Eastern Europe: Elite Purges and Mass Repression (Manchester, 2010), pp. 119-40.

5. Állambiztonsági Szolgálatok Történeti Levéltára (Historical Archives of State Security Services, henceforth ÁBTL) I. 1.b. (1500-208/60.a.) p. 5.

6. ÁBTL I. 13. -b. (V-142753), p. 8.

7. See e.g. ÁBTL I. 13. (V-142753), p. 29 (Testimony of Károlyné Döbrentei, 6 July 1955).

8. ÁBTL I. 13. (V-142753), p. 1.

9. ÁBTL I.1.e. V-142/673/5, pp. 296-8.

10. Magyar Országos Levéltár (Hungarian National Archive - henceforth MOL) 276. f. $65 .$, p. 6.

11. ÁBTL I. 13. (V-142753), p. 39.

12. Ibid., p. 43.

13. ÁBTL I. 13. -b. (V-142753), p. 27.

14. MOL 276. f. 65. cs. 52. öe., p. 219.

15. ÁBTL I. 13. (V-142753), p. 33. 


\section{PROOF}

De-Stalinisation in Hungary 65

16. Ibid., p. 29.

17. For the full text of the 1969 essay, which appeared in the magazine Kortárs in the form of a 'Letter to Aladár Mód', see Petô, Rajk Júlia, pp. 251-6.

18. ÁBTL I. 1.e. (V-142/673/5), pp. 239-46.

19. Ibid., Report on the spying of László Rajk, 26 August 1954, p. 247.

20. Baráth, 'Az MDP vezetése és a rehabilitáció'.

21. ÁBTL I.1.h. (V-143/415), p. 21.

22. ÁBTL I.1.e. (V-142/673/5), p. 286.

23. ÁBTL I. 1.b. p 63, report dated 12 November 1954. On Kádár, see Borhi, 'Stalinist Terror in Hungary', p. 133.

24. ÁBTL I. 1.b. (101-5446/1/54.), p. 59.

25. On this internal fight, see Baráth, 'Az MDP vezetése és a rehabilitáció', pp. 67-74.

26. MOL 276. f. 53. cs 227. öe., p. 111.

27. Ibid., p. 112.

28. MOL 276.f. 62/28.öe., p. 18. Letter of 17 March 1955 to László Piros.

29. ÁBTL I. 1.b., p. 72.

30. Ibid., p. 66. Report of 11 June 1955.

31. MOL 276. f. 53. cs. 250. Öe., p. 156. Report by Apró Antal on 3 October 1955.

32. ÁBTL I.1.h. V-143/415.

33. Quoted in Baráth, 'Az MDP vezetése és a rehabilitáció', p. 76.

34. ÁBTL I. 1.b., pp. 127-34.

35. ÁBTL I. 1. h. (V-143/415), p. 179.

36. Ibid.

37. All of the above quotes are taken from Suhajda's account of this meeting. See his autobiography, dated 2 September 1983, in Politikatörténeti Intézet Archivuma (Archive of the Institute of Political History) 867. f. 2/s-304., p. 46.

38. MOL 276. f. 65. cs. 52. öe. p. 267. Letter of 6 December 1955.

39. MOL 276. f. 65. cs. 52. öe., p. 262.

40. MOL 276. f. 65. cs. 52. öe., p. 270. Letter of February 1956.

41. MOL 276. f. 53. cs. 272., p. 17.

42. Open Society Archives, Budapest Rajk Lászlóné file, 205/12/0/101/18.

43. Gyula Rajk received 25,000 forints in cash, an apartment, and a monthly pension of 1,300 forints; Györk Lajosné was returned her holiday home; Jenőné Rajk was given a job; and Zoltán Rajk had his party membership restored and was admitted to the university with a scholarship. See MOL 276. f. 53. cs. 287. p. 72. Details of Júlia Rajk's financial compensation can be found at ÁBTL IX/6-1, p. 81. and IX/6.2., p. 10.

44. MOL 276. f. 53. cs. 272. öe., p. 17.

45. Ibid., p. 18.

46. On the Petőfi circle, see A. B. Hegedüs, 'The Petőfi Circle: The Forum of Reform in 1956', Journal of Communist Studies and Transition Politics, vol. 13, no. 2 (1997), pp. 108-33.

47. ÁBTL V-150001/5, p. 15. Testimony of István Márkus.

48. A. B. Hegedûs (ed.), A Petőfi Kör vitái hiteles jegyzókönyvek alapján (Minutes of the Petőfi Circle), Vol. 4: Partizántalákozó-Sajtóvita (Budapest, 1991), p. 203.

49. For the text of the speech, see Petô, Rajk Júlia, pp. 246-50.

50. MOL 276. f. 53. cs. 288. öe. 3 , 
66 Andrea Pető

51. For further details, see M. Potoky Strasser, Il mito che e' caduto: Ungheria 1945-1956 (Rome, 1991), pp. 113-20.

52. Discussions with Mrs Rajk, 10 December 1956, in Documents from Romania, 1956 Institute, p. 5.

53. Interview with Júlia Rajk by Bokor Péter, 1980, in Országos Széchenyi Könyvtár (National Széchenyi Library), Collection of Historical Interviews, 142. B., p. 53.

54. M. Baráth, 'Felemás desztalinizáció. A törvénysértések lezárása és az állambiztonsági szervek átszervezése Magyarországon 1962-ben', Betekintő, no. 3 (2012), pp. 8-9.

55. Ibid., p. 9. 


\section{Query Form}

\begin{tabular}{|l|l|}
\hline Book Title: & McDermott \\
\hline Chapter No: & Chapter 03 \\
\hline
\end{tabular}

Queries and / or remarks

\begin{tabular}{|l|l|l|}
\hline Query No. & \multicolumn{1}{|c|}{ Query / remark } & Response \\
\hline AQ1 & $\begin{array}{l}\text { Could you please provide the volume for the } \\
\text { endnote reference Baráth (1999)? }\end{array}$ & \\
\hline AQ2 & Should this be Mrs Faludi or something else? & $\begin{array}{l}\text { Might it be worth mentioning in brackets } \\
\text { as Államvédelmi Hatóság / State Protection } \\
\text { Authority, or do you think that would be } \\
\text { unnecessary information, beyond 'secret } \\
\text { police'? }\end{array}$ \\
\hline AQ4 & $\begin{array}{l}\text { Is this bracketed information required? } \\
\text { (I.e. As it is not a direct quote that you have } \\
\text { amended.) }\end{array}$ & \\
\hline AQ5 & $\begin{array}{l}\text { Her husband has not yet been mentioned in } \\
\text { the text - should he have been? }\end{array}$ & \\
\hline AQ6 & $\begin{array}{l}\text { Is it correct that more than one of her friends } \\
\text { said this (i.e. in chorus?) or might it reade } \\
\text { better as e.g. 'said one of Júlia's friends, many } \\
\text { of whom had...'? }\end{array}$ & \\
\hline AQ7 & $\begin{array}{l}\text { Please could you provide a volume for this } \\
\text { endnote reference Baráth (2012)? }\end{array}$ & \\
\hline AQ8 & $\begin{array}{l}\text { We have changed florints to forints in line } \\
\text { with other occurrences as well as online } \\
\text { sources; hope this is okay }\end{array}$ & \\
\hline
\end{tabular}

